\title{
FOREIGN EXPERIENCE OF SOCIAL SECURITY SYSTEMS FOR LAW ENFORCEMENT PERSONNEL
}

\author{
Nataliia Zolotarova' ${ }^{1}$, Hennadii Shevchuk ${ }^{2}$, Andrii Shevarikhin ${ }^{3}$
}

\begin{abstract}
The aim of the article is to analyse the foreign experience of the social security system of law enforcement personnel, to distinguish the features of establishing the rates and types of remuneration for law enforcement personnel in foreign countries, to determine the interrelation between the standard of social security and work experience and professional competencies. The subject of the study is the foreign experience of the social security system for law enforcement officials. Methodology. The study is based on a comparison of the social security system for law enforcement officials in Ukraine and in foreign countries. The analysis of the features of social security for law enforcement officers enabled to determine the advantages and disadvantages of different social security systems. A comparative legal study of certain provisions of Ukrainian legislation enabled to reveal the possibilities and limits of the application of positive foreign experience in this sphere. The results of the study revealed that in Ukraine the solution of problems on the performance improvement of law enforcement is interrelated with the issues of social security for personnel at work. Therefore, nowadays one of the main objectives is the development of a clear system of social security for law enforcement officers, including police officers, formation of an effective system of remuneration, based on performance indicators. Practical implications. In developed countries, the practice of social policy has formed several areas of its implementation. These include wage policy, social insurance, including medical, pension insurance, housing policy, as well as allowances and social benefits. Some aspects of social security for employees should be studied as a positive example for Ukraine in the course of social reforms. However, the application of foreign experience does not mean a mechanical transfer of certain forms of social security of foreign countries to Ukrainian reality. It should be considered that some aspects of reforming social security for law enforcement officers are universal; other aspects can be applied only under certain conditions related to the political situation in the country, the level of economic development, traditions, as well as the level of crime and criminalization of society. Relevance/originality. A comparative analysis of the ratio of social security systems for law enforcement officers is the basis for developing the most promising areas of domestic legislation in this sphere.
\end{abstract}

Key words: law enforcement bodies, police, social security, pay system.

JEL Classification: H53, 138

\section{Introduction}

One of the main tasks of the state is to ensure a decent standard of living for citizens. The high level of welfare, achieved due to high salaries and professional incentives for employees, enables to increase the efficiency of labour. This concerns the problems of performance improvement of law enforcement. The development of effective mechanisms to raise the material well-being of employees and satisfy their needs in decent housing, quality education, high-tech medical care, recreation are of great importance in solving these issues.

The foreign experience of developing pay and compensation systems, as well as social security for public officials and law enforcement personnel, can serve as a positive example for Ukrainian public administration bodies in the course of social reform.

In 2015, under the large-scale reform of the law enforcement bodies, the enactment of a package of social security documents was only the first step towards improving the system of social security for police personnel.

These documents include the Law of Ukraine "On the National Police" (Pro Natsionalnu politsiiu), the Law of Ukraine "On Pension Provision of Persons Discharged from Military Service and Some Other Persons" (Pro pensiine zabezpechennia osib, zvilnenykh $\mathrm{z}$ viiskovoi sluzhby, ta deiakykh inshykh osib), the Resolution of the Cabinet of Ministers of Ukraine "On Approval of the Regulation on the National Police"

\footnotetext{
Corresponding author:

${ }^{1}$ National Academy of Internal Affairs, Ukraine.

${ }^{2}$ National Academy of Internal Affairs, Ukraine.

${ }^{3}$ National Academy of Internal Affairs, Ukraine.
} 
(Pro zatverdzhennia Polozhennia pro Natsionalnu politsiiu), the Resolution of the Cabinet of Ministers of Ukraine "On the Remuneration of Police Officers of the National Police" (Pro hroshove zabezpechennia politseyskykh Natsionalnoi politsii), the Resolution of the Cabinet of Ministers of Ukraine "On Procedure of computation of the length of service, assignment and payment of pensions and allowances for officers, warrant officers, sub-officers, extended military servicemen and enlisted by contract, persons of senior commanders and junior enlisted of the Internal Affairs Bodies, and police officers as well as members of their families" (The Cabinet of Ministers of Ukraine, 1992), the Order of the Ministry of Internal Affairs of Ukraine "On Approval of the Procedure and conditions for payment of remuneration for police officers of the National Police and cadets of higher educational institutions of the Ministry of Internal Affairs with specific learning conditions" (The Ministry of Internal Affairs of Ukraine, 2016) etc. Nevertheless, there is still much work to be done for improving the system of social security for police officers in Ukraine, which determines the relevance of the chosen topic.

The aim of the article is to analyse the foreign experience of a social security system for law enforcement personnel, to distinguish the features of establishing the rates and types of remuneration for law enforcement personnel in foreign countries, to determine the interrelation between the standard of social security and work experience and professional competencies.

\section{The main material}

Foreign experience in social security for civil servants demonstrates that pay and social security systems differ from each other. It depends on many factors, including historical experience, legal and economic system of the country, traditions.

In some developed countries, the salary of civil servants of the "middle level" is based on the rate of remuneration of the "middle class" in the country in general. In addition, in these countries, the state provides civil servants with a high standard of social guarantees.

For example, Japan ranks first in the world by salary rates of the middle- and upper-level civil servants. It is legally established that remuneration of officials should correspond to the general position in society. In the performance of certain duties, employees of state bodies, as well as employees of the private sector of the economy, should receive appropriate remuneration for their work, knowledge, and skills. Therefore, salaries in the public and private sectors should be maintained at the same rate. To resolve this problem, Recommendations are made to amend the Law on Salaries of Civil Servants, which consider a salary research in the private and public sectors, as well as the wishes and opinions of ministries and departments. In addition, civil servants, including law enforcement officials in Japan, are provided with a "social package" that includes treatment, leave, child retention, transport and regional assistance (Andriichuk, 2016).

In other foreign countries, such as the United Kingdom, Germany, remuneration of civil servants and law enforcement officers is lower than of similar positions in the private sector. However, the state tries to ensure financial and social independence and a decent standard of living for employees, adequate to the standard of living in the country and corresponding to their social status.

In some foreign countries, traditionally salaries are increased annually; for example, for law enforcement officials in Austria, pay growth depends partly on seniority, professional experience, capabilities of an employee, and special working conditions.

Some foreign countries pay great attention to social security for public officials. For example, in Finland, the right to social security is one of the fundamental rights of any citizen. The system of social security in Finland is based on the so-called "Scandinavian model" of a social state. The main characteristics of this model are the principle of universality, financing via high taxation, equal treatment of all people, and a high level of social benefits.

In Italy and Spain, the system of social security for law enforcement personnel also plays an important role. The basic salary is only $40 \%$ of the total employee income. Additional social benefits of up to $50 \%$ of the salary depend on the official's place of residence, his family status, professional experience, and other factors. The remaining $10 \%$ is due to special conditions of service or specialty.

Systems of remuneration, material incentives, and social security for civil servants of foreign countries also vary due to the model of civil service accepted in the country, such as the career or position model.

In countries with the career system, civil service is based on traditional principles of management, that is, the state undertakes to provide its employees with the social and financial provision. For example, in Germany, the constitutional basis for remuneration of officials is the "content principle", which is one of the basic legal principles regarding the status of civil servants.

The rate of a civil servant's salary depends significantly on his/her education, professional qualifications, skills and abilities in this type of activity. At the same time, the rate of remuneration of civil servants should be adequate to the social status of an employee, so that he/she would be able to maintain an appropriate lifestyle. However, the salaries of civil servants are lower than those of private sector employees. 
Nevertheless, this difference is compensated by social guarantees and social security provided to civil servants (Shymanovska, 2009).

In contrast to countries with the career system of public service (uniform salaries are provided for by the legislation), in countries with the position system, salaries are determined by different departments considering the budget funds, allocated to them, in accordance with collective agreements concluded between the relevant government body and trade unions as representatives of civil servants.

In the United States, Canada, the United Kingdom, France, countries with the position system of civil service, more individual and flexible forms and systems of remuneration of employees prevail in comparison with the countries with the career civil service system that are close to the private sector of the economy.

Moreover, a number of countries consider improving the efficiency of human resources in state regulation and protection of the law. Evidently, each state forms and develops its systems of efficiency grading and the forms of incentive for law enforcement personnel based on their experience, political, social, and economic situation in the country.

For example, the basis of the US civil service is the merit system, when any employee should receive fair treatment (recruitment, promotion, lowering the position, etc.) due to his/her abilities and personal qualities.

The United States police payroll scale is a table where the levels of pay are determined vertically, while the length of service of an employee is indicated horizontally. Therefore, the salary rate increases diagonally.

The United States also has a well-developed system of social security for civil servants, including a system of benefits. For example, the "social package" of the US police officer is very high. Police officers are very interested in it and consequently, it encourages effective performance and eagerness to stay at police service as long as the retirement age (Driakhlov, Kupriianov, 2012).

In France, one of the main rights of civil servants is the right to remuneration, which consists of three parts, such as basic salary, additional remuneration, and social benefits and preferences. Moreover, the basic salary is paid according to a rigid system. At the beginning of a career, employees receive, as a rule, less than employees of state-owned enterprises or commercial organizations do. Nevertheless, during the service, the salary of a civil servant increases and at the end of the service, he/she usually receives more. This ensures the stability of the socioeconomic status of employees and their confidence in the future. Basic salary is a guaranteed remuneration. However, often it is insufficient. Therefore, the legislation provides for additional allowances and payments. In addition, in France, each department has the right to reduce expenses on infrastructure (office transport, business trips, maintenance costs), and create fiscal space for an increase in employee salaries (Diadechko, 2010).

Pay and incentive systems of foreign countries differ from each other also by interrelation between salaries and professional performance.

For example, the salary of most Canadian civil servants is not linked to professional performance. Only 3-4\% of civil servants receive salaries, which depend on professional performance. The remaining $96 \%$ are paid according to a fixed wage scale. There are about 50 professional categories in Canada. Inside each category, there is an additional scale for determining the level of work complexity.

The United Kingdom exemplifies a contrasting approach to such a system; in 1984, the system of remuneration for civil servants, based on the assessment of the efficiency of performance on the results of the performance certification, was introduced. At present, one of the most important principles of the system of financial provision for civil servants in the UK is the necessity of incentives. The direct interdependence of the rate of remuneration on the achievements of professional performance is among such incentives. The only exception is senior executives because their salary rate is established individually considering the degree of responsibility, performance efficiency, professional experience and qualifications.

\section{Conclusion}

Therefore, it should be noted that in some foreign countries, the system of financial provision for civil servants and law enforcement officials is based on the salary rates of employees of the commercial sector of the economy. In other countries, the remuneration of civil servants is much lower than that of private sector employees. However, these states pay much attention to the social security of civil servants to ensure a decent standard of their living, adequate to living standards in the country and the corresponding socio-economic status of civil servants. In some foreign countries, the pay and incentive system is based on the professional performance of civil servants; in other countries, salaries of civil servants practically do not depend on the results of their work. In a number of foreign countries, the flexible system of financial incentives for civil servants exists; in other countries, the rigid system of remuneration and social security measures prevails. Moreover, in most civilized countries, civil service and law enforcement are one of the most prestigious employments. It is believed that a person on a civil service position is a representative of the state and society, a defender of their rights and legitimate interests. 


\section{References:}

Pro Natsionalnu politsiiu [On National Police]. Law of Ukraine of July 2, 2015. Retrieved from: http://zakon2.rada.gov.ua/laws/show/580-19 (in Ukrainian)

Pro pensiine zabezpechennia osib, zvilnenykh z viiskovoi sluzhby, ta deiakykh inshykh osib [On pension provision of persons discharged from military service and some other persons]. Law of Ukraine of April 9, 1992. Retrieved from: http://zakon5.rada.gov.ua/laws/show/2262-12 (in Ukrainian)

The Cabinet of Ministers of Ukraine (2015). Pro zatverdzhennia Polozhennia pro Natsionalnu politsiiu [On approval of the Regulation on the National Police]. Resolution no. 877 of October 28, 2015. Retrieved from: http://zakon3.rada.gov.ua/laws/show/877-2015-\%D0\%BF/paran9\#n9 (in Ukrainian)

The Cabinet of Ministers of Ukraine (2015). Pro hroshove zabezpechennia politseyskykh Natsionalnoi politsii [On the remuneration of police officers of the National Police]. Resolution no. 988 of November 11, 2015. Retrieved from: https://www.kmu.gov.ua/ua/npas/248668490 (in Ukrainian)

The Cabinet of Ministers of Ukraine (1992). Pro poriadok obchyslennia vysluhy rokiv, pryznachennia ta vyplaty pensii i hroshovoi dopomohy osobam ofitserskoho skladu, praporshchykam, michmanam, viiskovosluzhbovtsiam nadstrokovoi sluzhby ta viiskovoi sluzhby za kontraktom, osobam nachalnytskoho i riadovoho skladu orhaniv vnutrishnikh sprav, politseyskym ta chlenam yikhnikh simey [On procedure of computation of length of service, assignment and payment of pensions and allowances for officers, warrant officers, sub-officers, extended military servicemen and enlisted by contract, persons of senior commanders and junior enlisted of the Internal Affairs Bodies, and police officers as well as members of their families]. Resolution no. 393 of July 17, 1992. Retrieved from: http://zakon5.rada.gov.ua/laws/show/393-92-\%D0\%BF (in Ukrainian)

The Ministry of Internal Affairs of Ukraine (2016) Pro zatverdzhennia Poriadku ta umov vyplaty hroshvoho zabezpechennia politseyskym Natsionalnoi politsii ta kursantam vyshchykh navchalnykh zakladiv MVS iz spetsyfichnymy umovamy navchannia [On approval of the Procedure and conditions for payment of remuneration for police officers of the National Police and cadets of higher educational institutions of the Ministry of Internal Affairs with specific learning conditions]. Order no. 260 of April 06, 2016. Retrieved from: http://zakon5.rada.gov.ua/ laws/show/z0669-16 (in Ukrainian)

Andriichuk, Yu.A. (2016). Zarubizhnyi dosvid motyvatsii personalu v rozrizi yaponskoi modeli [Foreign experience of personnel motivation in the Japanese model]. Visnyk Natsionalnoho universytetu "Lvivska politekhnika". Lohistyka, 846, 11-15. (in Ukrainian)

Shymanovska, R. (2009). Zarubizhnyi dosvid derzhavnoho rehuliuvannia zarobitnoi platy. [The foreign experience of state regulation of salaries]. Zbirnyk naukovykh prats Natsionalnoi akademii derzhavnoho upravlinnia pry Prezydentovi Ukrainy, 1, 117-126. (in Ukrainian)

Driakhlov, N., Kupriianov, E. (2012). Sistemy motivatsii personala v zapadnoi Yevrope i SShA [Personnel motivation systems in Western Europe and the USA]. Problemy teorii i praktiki upravleniia, 2, 83-88. (in Russian)

Diadechko, L. P. (2010). Motyvatsiia personalu v systemi efektyvnoho funktsionuvannia transnatsionalnykh korporatsii [Personnel motivation in the system of efficient functioning of transnational corporations]. Ekonomicheskie nauki, 8, 5-6. (in Ukrainian) 